\title{
Хірургічні аспекти перитонеального діалізу: профілактика, діагностика та лікування ускладнень
}

Мета - провести аналіз ускладнень, які виникають під час перитонеального діалізу, та вивчити результати їх профілактики та лікування. Об'єкт і методи дослідження. Проаналізовано результати лікування 54 пацієнтів із хронічною хворобою нирок, яким проводили нирковозамісну терапію методом перитонеального діалізу. Профілактика ускладнень включала передопераційну підготовку, ретельне дотримання правил встановлення катетера, післяопераційний догляд за катетером. Результати. Ускладнення розвинулися у 18(33,3\%) осіб, у 10(18,5\%) вони мали інфекційний характер (інфекція місця виходу катетера, тунельна інфекція, перитоніт). Основними збудниками ускладнень були Staphylococcus aureus, Pseudomonas aeruginosa тa Staphylococcus epidermidis. Неінфекційні ускладнення (перикатетерне витікання діалізату, міграція катетера) відмічали у 8(14,8\%) випадках. У лікуванні застосовували комплексний диференційований підхід. До видалення катетера довелося вдатися у 3 випадках. Летальних випадків, пов'язаних із ускладненнями перитонеального діалізу, не було. Висновки. Ефективність перитонеального діалізузалежить від правильності встановлення катетера, проведення профілактичних заходів для запобігання інфекційним ускладненням та порушенню функціонування катетера, своєчасної діагностики та патогенетично обґрунтованого лікування.

Ключові слова: хронічна хвороба нирок, перитонеальний діаліз, інфекція місця виходу катетера, тунельна інфекція, перитоніт, перикатетерне витікання діалізату, міграція катетера.

\section{Вступ}

Хронічна хвороба нирок (XXH) є неминучим наслідком практично всіх нефропатій незалежно від їх походження. На сьогодні прогресивне зростання кількості хворих із термінальною нирковою недостатністю набуває характеру пандемії та охоплює майже усі країни, виводячи XXН у ранг важливої медичної та соціальної світової проблеми (Толстанов О.K., 2013; Mangione F., Dal Canton A., 2014).

у Європейських дослідженнях виявили значну різницю показників XXН у населення континенту: від 3,31\% - у Норвегії до 17,3\% - у Північно-Східній Німеччині. У США 30 млн осіб, або $15 \%$ дорослих американців, мають XXН. Згідно з даними досліджень, у Китаї налічують 119,5 млн хворих, що становить 10,8\% населення (Xueqing Y., Xiao Y., 2015; Brück K., 2016; Centers for Disease Control and Prevention, 2017).

Медичні витрати, пов'язані з XXН, $€$ істотними навіть на ранніх стадіях і зростають у міру прогресування захворювання. Так, у Нiмеччині середні щорічні економічні витрати на одного хворого на XXН становлять 3581 євро. В Італії лікування одного такого пацієнта оцінюють від 890 євро на III до 13752 євро - на V стадії. У США щорічні витрати на одну особу з XXН становлять 1700 дол. на II стадії та 12700 дол. - на IV, а в цілому у країні витрачається на лікування цих хворих близько 49 млрд дол. на рік. Вартість лікування пацієнта з термінальною стадією XXH у Китаї сягає 13850 15380 дол. (Honeycutt A.A. et al., 2013; Xueqing Y., Xiao Y., 2015; Turchetti G. et al., 2017)

В Україні останніми роками відмічають неухильне зростання кількості хворих на XXH. Захворювання III-V стадії мають 31523 особи, із них V стадію - 9214 (21,9 на 100 тис. населення) (Колесник М.О., 2017).

Використання методів нирковозамісної терапії (НЗТ) дозволяє збільшити тривалість життя Хворих на XXH, а також забезпечити достатній рівень ії якості. На сьогодні у світовій практиці успішно застосовують концепцію лікування хворих із термінальною стадією XXH, яка передбачає поєднання методик НЗТ: гемодіалізу, перитонеального діалізу (ПД) і трансплантації (Лесовой В.Н. и соавт., 2011).

У 2016 р. в Україні НЗТ отримували 8019 осіб, із них ПД - 915 (у 2014 р. - 806). Для проведення сеансів ПД на одного хворого (залежно від типу та стадії хвороби) на рік витрачається 351,41230,0 тис. грн. (дані 2015 р.) (Гетало О.В., 2015; Колесник М.О., 2015; 2017)

ПД зарекомендував себе як ефективний метод НЗТ, результати застосування якого не поступаються гемодіалізу. Завдяки низці переваг, у тому числі можливості виконання процедури хворими самостійно у домашніх умовах, застосування ПД $є$ досить частим. Ця його особливість найбільше актуальна для населення невеликих міст, селищ та сіл, де низька щільність населення і неможливе створення центрів гемодіалізу (Толстанов О.К., 2013; Gonçalves F.A. et al., 2015; Xueqing Y., Xiao Y., 2015).

Попри те що ПД досить давно і широко впроваджений у практику та постійно вдосконалюється, все ж можливе виникнення ускладнень. Останні найчастіше пов'язані з функціонуванням катетера та розвитком інфекційних процесів і потребують корекції, від швидкості проведення якої часто залежить можливість подальшого застосування методики у лікуванні XXН та її ефективність (Sinangil A. et al., 2013; Miftah M. et al., 2014; Мішалов В.Г. та співавт., 2015).

Мета - провести аналіз ускладнень, які виникають під час ПД, та вивчити результати їх профілактики та лікування у хворих на XXH.

\section{Об'єкт і методи дослідження}

Проаналізовано результати лікування 54 пацієнтів із XXH, яким проводили НЗТ методом ПД у Сумській обласній клінічній лікарні в період 2006-2018 рр. Із них жінок було 33 (61,6\%), чоловіків - 21 (38,9\%), вік хворих - 19-74 роки (середній вік $42,5 \pm 5,4$ року).

Причинами розвитку XXH були хронічний гломерулонефрит, цукровий діабет, гіпертонічна хвороба, хронічний пієлонефрит, системні захворювання, полікістоз нирок. У низці випадків встановити причину розвитку XXН не вдалося (табл. 1).

У доопераційний період хворим проводили клініко-лабораторні обстеження, ультразвукове дослідження органів черевної порожнини, за необхідності застосовували рентгенологічні методи діагностики та ін.

Для проведення ПД застосовували катетери фірми «Tenkoff» із двома дакроновими манжетами. Використовували діалізні роз- 
чини фірми «Baxter» та «Fresenius». Катетер у черевну порожнину встановлювали в умовах операційної за класичною відкритою методикою, під місцевим знеболенням. Місце імплантації вибирали з урахуванням наявності післяопераційних рубців, грижових випинань та особливостей анатомії передньої черевної стінки. Перевагу надавали розташуванню катетера справа від пупка, розміщуючи його глибоку манжету у піхві прямого м'яза живота. Це сприяло кращому вживленню манжети через інтенсивну васкуляризацію м'язової тканини та забезпечувало оптимальну фіксацію катетера з більш повною його ізоляцією, знижуючи тим самим ризик підтікання діалізату. Внутрішньоочеревинний сегмент катетера розташовували типово в найбільш глибокій точці малого таза.

Таблиця 1. Причини XXH

\begin{tabular}{lcccccc}
\hline \multirow{2}{*}{\multicolumn{1}{c}{ Причини XXH }} & \multicolumn{2}{c}{ чоловіки } & \multicolumn{2}{c}{ Жінки } & \multicolumn{2}{c}{ Усього } \\
\cline { 2 - 7 } & $\mathbf{n}$ & $\%$ & $\mathbf{n}$ & $\%$ & $\mathbf{n}$ & $\%$ \\
\hline Хронічний гломерулонефрит & 13 & 24,1 & 18 & 33,3 & 31 & 57,4 \\
Цукровий діабет & 3 & 5,6 & 6 & 11,1 & 9 & 16,7 \\
Хронічний пієлонефрит & 3 & 5,6 & 5 & 9,3 & 8 & 14,8 \\
Інші & 2 & 3,7 & 1 & 1,9 & 3 & 5,6 \\
Не встановлено & 1 & 1,9 & 2 & 3,7 & 3 & 5,6 \\
Загалом & 22 & 40,7 & 32 & 59,3 & 54 & 100 \\
\hline
\end{tabular}

Важливим етапом імплантації перитонеального катетера була підготовка хворого. Ї̈̈ проводили за загальноприйнятою схемою, яка включала гігієнічні заходи, підготовку кишечнику та введення антибіотиків з метою профілактики інфекційних ускладнень. Відмітимо, що очищення кишечнику має важливе значення в плані правильного внутрішньочеревного розташування катетера і знижує ризик травматизації кишечнику. Антибіотикопрофілактику проводили до або під час втручання, використовуючи переважно середньотерапевтичні дози цефалоспоринів III покоління, що дозволило практично повністю запобігти розвитку інфекційних ускладнень у ранній післяопераційний період.

Після імплантації катетера накладали асептичну пов'язку. Протягом 2 тиж до заживлення отвору стежили за місцем введення катетера, виконуючи перев'язки. У подальшому місце виходу катетера щоденно обробляли водою з бактерицидним милом, після чого накладали серветку з антисептиком. Для запобігання травматизації зовнішнього отвору стежили, щоб зовнішня частина катетера завжди була іммобілізована.

\section{Результати та їх обговорення}

Серед 54 осіб, яким проводили ПД, ускладнення розвинулися у $18(33,3 \%)$. Серед них було $11(61,1 \%)$ жінок та $7(38,9 \%)$ чоловіків. Середній вік хворих становив $46,2 \pm 4,2$ року. Ускладнення інфекційного характеру (інфекція місця виходу катетера, тунельна інфекція, перитоніт) відмічали у 10 (18,5\%), неінфекційні (перикатетерне витікання діалізату, міграція катетера) - у 8 (14,8\%) хворих.

Інфікування зовнішнього отвору спостерігали у 2 (3,7\%) осіб. Його проявами класично вважали біль, гіперемію, набряк, виділення в ділянці виходу катетера. Ускладнення розвивалося в середньому через $34,2 \pm 6,1$ доби після встановлення катетера.

У 2 (3,7\%) хворих діагностували тунельну інфекцію, ознаками якої були почервоніння, набряк, біль у напрямку катетера, гнійні виділення з отвору виходу катетера. Середній строк розвитку ускладнення становив $42,7 \pm 9,3$ доби після початку процедури ПД.

Згідно з результатами бактеріологічного дослідження етіологічними агентами вищезазначених ускладнень були Staphylococcus aureus, Pseudomonas aeruginosa та Staphylococcus epidermidis (табл. 2).

Тактика лікування за розвитку інфекції зовнішнього отвору та тунельної інфекції залежала від вираженості клінічних проявів. У разі відсутності гнійних виділень, гіперемії та набряку проводили місцеву терапію, використовуючи гіпертонічний розчин натрію хлориду та крем, що містить антибіотик, наносячи його на стерильну серветку, якою обгортали місце виходу катетера. Перев'язки виконували 2-3 рази на добу. При розвитку гіпергрануляцій у ділянці зовнішнього отвору проводили їх коагуляцію.

Поява гною потребувала проведення антибіотикотерапії. За наявності грампозитивної мікрофлори перевагу надавали введенню цефалоспоринів II-III покоління, грамнегативної фторхінолонів, для боротьби з метицилінрезистентним Staphylococcus aureus застосовували ванкоміцин. Препарати застосовували у середньотерапевтичних дозах. Антибактеріальну терапію проводили до усунення ознак запалення зовнішнього отвору та тунельної інфекції, але не менше 2 тиж. Середня тривалість лікування становила 15,3ะ3,9 доби.

В 1 (1,9\%) випадку лікування не мало позитивного ефекту, що призвело до необхідності видалення катетера

У $6(11,1 \%)$ хворих відмічали розвиток перитоніту, ранніми ознаками якого були помутніння діалізату зі зменшенням його об'єму та біль у животі, менш частими - гіпертермія, нудота, діарея. При безпосередньому обстеженні виявляли типові симптоми перитоніту: біль у животі, ослаблення кишкових шумів, болісність і напруження черевної стінки при пальпації.

Термін розвитку перитоніту становив 3-36 міс з початку пд (у середньому 14,2 $\pm 7,2$ міс).

Усім хворим за підозри на наявність перитоніту обов'язково проводили ультразвукове та інші методи дослідження органів черевної порожнини для виявлення гострих запальних захворювань, які могли б викликати розвиток цього ускладнення. За результатами мікроскопії та бактеріологічного дослідження діалізного розчину підтверджували діагноз (див. табл. 2).

Таблиця 2. Етіологічні агенти інфекційних ускладнень ПД

\begin{tabular}{lcccccc}
\hline \multirow{2}{*}{ 3будник } & \multicolumn{5}{c}{ Вид ускладнення } \\
\cline { 2 - 7 } & $\begin{array}{l}\text { Інфекція місця } \\
\text { виходу катетера }\end{array}$ & $\begin{array}{l}\text { Тунельна } \\
\text { інфекція }\end{array}$ & Перитоніт \\
\cline { 2 - 7 } & $\mathbf{n}$ & $\%$ & $\mathbf{n}$ & $\%$ & $\mathbf{n}$ & $\%$ \\
\hline Staphylococcus aureus & 1 & 10 & 1 & 10 & 2 & 20 \\
Pseudomonas aeruginosa & - & - & 1 & 10 & 1 & 10 \\
Staphylococcus epidermidis & 1 & 10 & - & - & - & - \\
Candida albicans & - & - & - & - & 1 & 10 \\
3будник не ідентифіковано & - & - & - & - & 2 & 20 \\
Усього & 2 & 20 & 2 & 20 & 6 & 60 \\
\hline
\end{tabular}

Лікування перитоніту розпочинали до ідентифікації збудника шляхом введення цефалоспоринів III покоління, аміноглікозидів або фторхінолонів, комбінуючи препарати так, щоб вони впливали як на грампозитивну, так і на грамнегативну мікрофлору. Після отримання результатів бактеріологічного дослідження проводили корекцію антибактеріальної терапії відповідно до чутливості мікроорганізмів. Використовували переважно внутрішньовенний та інтраперитонеальний (з діалізним розчином) шляхи введення антибіотиків. Дозу препаратів коригували залежно від функціональної здатності нирок. У випадку грибкового перитоніту застосовували внутрішньовенне введення флуконазолу. Також проводили симптоматичну терапію та лікування основного захворювання.

Необхідно відмітити, що протягом лікування бактеріологічне дослідження діалізного розчину проводили в динаміці з метою верифікації можливих змін мікрофлори та корекції антибіотикотерапії. Особливо на це звертали увагу у разі негативних результатів бактеріологічних посівів.

У більшості хворих позитивної динаміки досягнуто вже через 48 год. Тривалість лікування перитоніту становила 14-19 діб (у середньому $-15,4 \pm 4,2$ доби). До видалення перитонеального катетера довелося вдатися у 2 випадках.

Ускладнення ПД, пов'язані з дисфункцією катетера, відмічали у $8(14,8 \%)$ осіб. У $6(11,1 \%)$ із них відбулося зміщення (міграція) катетера, у 2 (3,7\%) - перикатетерне витікання діалізату.

Підставами для підозри про диспозицію катетера були больові відчуття у черевній порожнині під час проведення діалізу та невідповідність введеного об'єму розчину злитому. Зміщення підтверджували за допомогою ультразвукової діагностики та оглядової рентгенографії органів черевної порожнини (рис. 1, 2).

Найбільш ранній випадок міграції катетера зафіксували через 5 діб після імплантації, найпізніший - через 140 діб. За допомогою консервативних заходів (профілактика та лікування запорів, режим заливок у положенні напівлежачи) вдалося усунути міграцію катетера у 2 (3,7\%) хворих, у 4 (7,4\%) пацієнтів катетер встановили повторно.

Витікання діалізного розчину відмічали у 2 (3,7\%) хворих. Це ускладнення розвивалося на 2-гу-3-тю добу після встановлення 


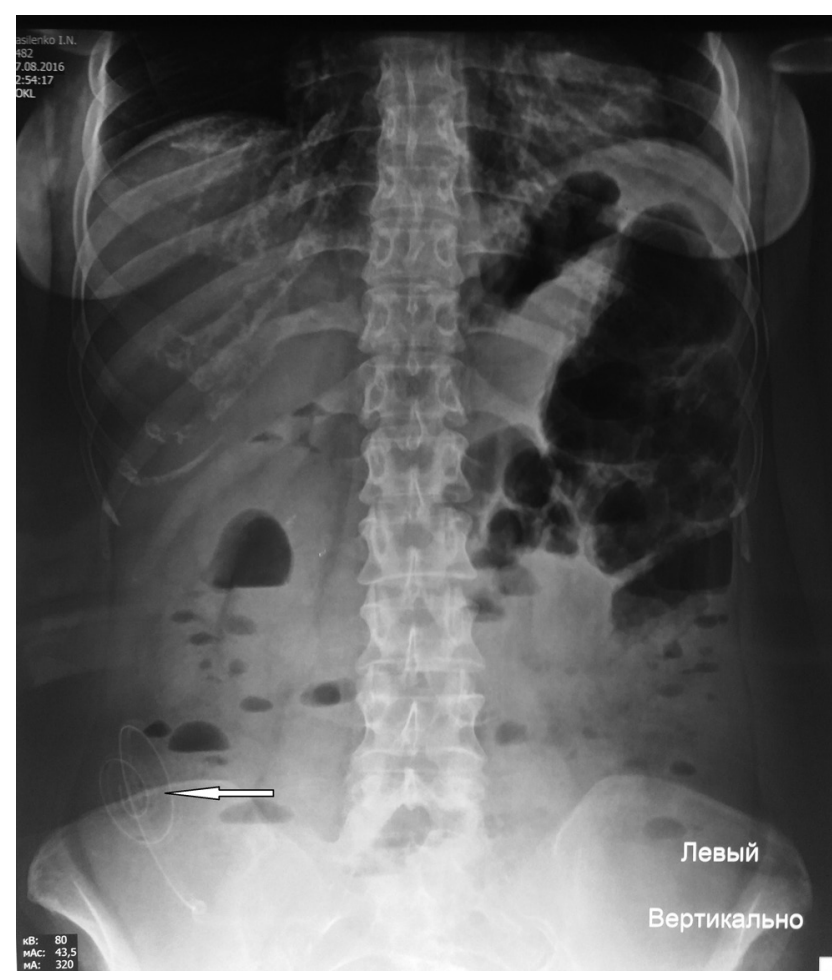

Рис. 1. Оглядова рентгенограма органів черевної порожнини. Хвора П., 42 роки. Міграція катетера у праву здухвинну ділянку

катетера та тривало в середньому 5,3 22,5 доби. В 1 (1,9\%) випадку витікання розчину припинилося самостійно після зменшення об'єму діалізату, який вводили у черевну порожнину. Другий хворий потребував повторного встановлення катетера.

Летальних випадків, пов'язаних із ускладненнями ПД, не було.

\section{Висновки}

ПД $€$ сучасним методом лікування при XXH, ефективність якого залежить від низки факторів. До них відносять технічно правильне встановлення катетера, проведення профілактичних заходів для запобігання інфекційним ускладненням та порушенню функціонування катетера, а також своєчасну діагностику та вчасно розпочате патогенетично обґрунтоване лікування. Вищеперераховане сприяє тривалому функціонуванню катетера і, відповідно, подовжує строк перебування хворих на ПД.

\section{Список використаної літератури}

Гетало О.В. (2015) Моніторинг вартості застосування засобів для перитонеального діалізу у хворих на хронічну хворобу нирок. Соц. фармація в охор. здоров'я, 1(2): 82-87.

Колесник М.О. (ред.) (2015) Національний реєстр хворих на хронічну хворобу нирок: 2014 рік. ДУІН НАМН України, Київ, 202 с.

Колесник М.0. (ред.) (2017) Національний реєстр хворих на хронічну хворобу нирок та пацієнтів з гострим пошкодженням нирок: 2016 рік. ДУІН НАМН України, Київ, 201 с.

Лесовой В.Н., Андоньева Н.М., Гуц Е.А. и др. (2011) Применение перитонеального диализа как метода коррекции уремического синдрома у пациентов с хронической болезнью почек. Междунар. мед. журн., 3: 95-100.

Мішалов В.Г., Заводовський Є.С., Маркулан Л.Ю. та ін. (2015) Фактори ризику діалізного перитоніту (трирічне проспективне дослідження) Клін. хір., 9: 23-25.

Толстанов О.К. (2013) Сучасний підхід до розвитку нирковозамісної терапії методом перитонеального діалізу. Сучасні медичні технології, 4: 5-8.

Brück K. (2016) Epidemiology of chronic kidney disease in Europe. University of Amsterdam, $291 \mathrm{p}$.

Centers for Disease Control and Prevention (2017) National chronic kidney disease fact sheet. US Department of Health and Human Services, Atlanta, GA.

Gonçalves F.A., Dalosso I.F., Camargo Borba J. M. et al. (2015) Quality of life in chronic renal patients on hemodialysis or peritoneal dialysis: a comparative study in a referral service of Curitiba - PR. J. Bras. Nefrol., 37(4): 467-474.

Honeycutt A.A., Segel J.E., Zhuo X. et al. (2013) Costs of CKD in the Medicare Population. JASN, 24(9): 1478-1483.

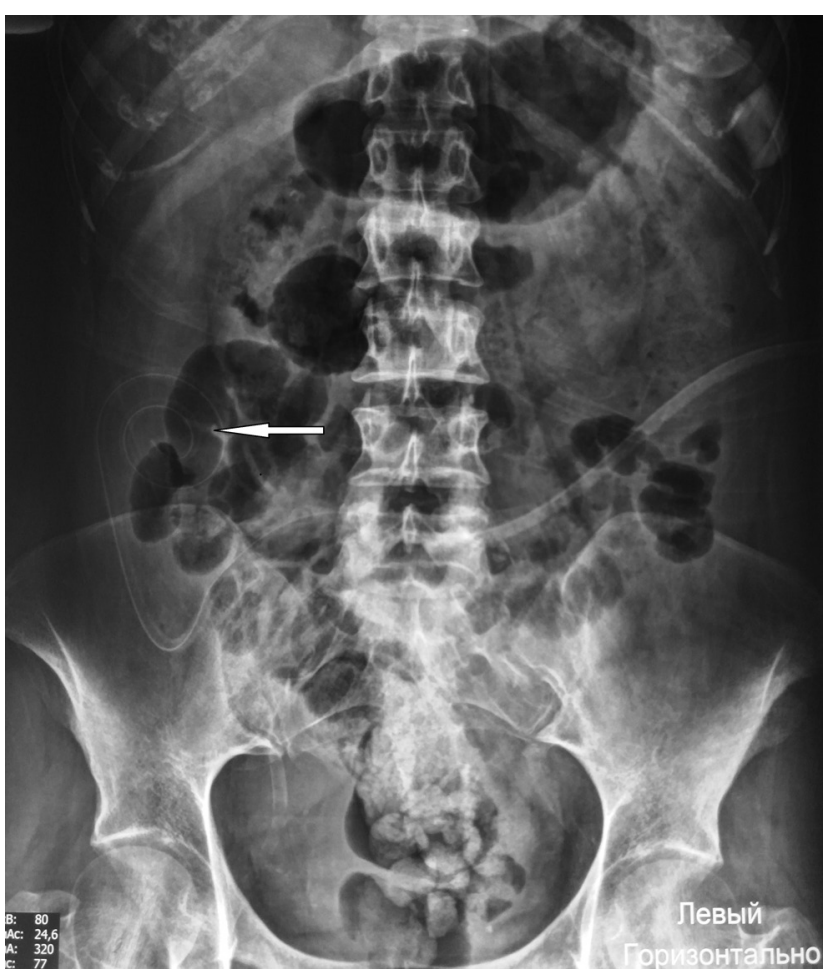

Рис. 2. Оглядова рентгенограма органів черевної порожнини. Хворий К., 36 років. Міграція катетера у ділянку правого бокового каналу

Mangione F., Dal Canton A. (2011) Chronic kidney disease epidemic: myth and reality. Intern. Emerg. Med., 6 (1): 69-76.

Miftah M. , Asseban M. , Bezzaz A. et al. (2014) Mechanical complications of peritoneal dialysis. Open J. Nephrol., 4(3): 103-109.

Sinangil A. , Koc Y. , Unsal A. et al. (2013) Effects of infectious complications on patients' survival in peritoneal dialysis. Eur. Rev. Med. Pharmacol. Sci., 17: 1064-1072.

Turchetti G., Bellelli S., Amato M. et al. (2017) The social cost of chronic kidney disease in Italy. Eur. J. Health Econ., 18(7): 847-858.

Xueqing Y., Xiao Y. (2015) Peritoneal dialysis in China: meeting the challenge of chronic kidney failure. Am. J. Kidney Dis., 65(1): 147-151.

\section{Хирургические аспекты перитонеального диализа: профилактика, диагностика и лечение осложнений}

\section{А.В. Кравец, И.А. Мысловский, В.М. Попадинец}

Резюме. Цель - провести анализ осложнений, возникающих во время перитонеального диализа, и изучить результаты их профилактики и лечения. Объект и методы исследования. Проанализированы результаты лечения 54 пациентов с хронической болезнью почек, которым проводили почечнозаместительную терапию методом перитонеального диализа. Профилактика осложнений включала предоперационную подготовку, тщательное соблюдение правил установки катетера, послеоперационный уход за катетером. Результаты. Осложнения развились у 18 (33,3\%) человек, у 10 (18,5\%) они имели инфекционный характер (инфекция места выхода катетера, туннельная инфекция, перитонит). Основными возбудителями осложнений были Staphylococcus aureus, Pseudomonas aeruginosa и Staphylococcus epidermidis. Неинфекционные осложнения (перикатетерное вытекание диализата, миграция катетера) отмечали в 8(14,8\%) случаях. В лечении применяли комплексный дифференцированный подход. К удалению катетера пришлось прибегнуть в 3 случаях. Летальных исходов, связанных с осложнениями перитонеального диализа, не было. Выводы. Эффективность перитонеального диализа зависит от правильности установки катетера, проведения профилактических мероприятий для предупреждения инфекционных осложнений и нарушения функционирования катетера, своевременной диагностики и патогенетически обоснованного лечения.

Ключевые слова: хроническая болезнь почек, перитонеальный диализ, инфекция места выхода катетера, туннельная инфекция, перитонит, перикатетерное истечение диализата, миграция катетера. 


\section{ОРИГІНАЛЬНІ ДОСЛІДЖЕННЯ}

\section{Surgical aspects of peritoneal dialysis: prevention, diagnosis and treatment of complications \\ O.V. Kravets, I.A. Myslovskyi, V.M. Popadynets}

Resume. Aim - to analyze the complications that arise during peritoneal dialysis and to study the results of their prevention and treatment Object and methods of research. The results of treatment of 54 patients with chronic kidney disease, which was carried out by renal replacement therapy by the method of peritoneal dialysis, were analyzed. Prevention of complications included preoperative preparation, careful observance of the rules for the catheter implantation, postoperative care of the catheter. Results. Complications developed in 18(33.3\%) people. In 10(18.5\%) patients, they were infectious (catheter exit site infection, the tunnel infection, peritonitis). Staphylococcus aureus, Pseudomonas aeruginosa and Staphylococcus epidermidis were the main causes of complications. Non-infectious complications (pericateretric leakage of dialysis, catheter migration) were observed in $8(14.8 \%)$ cases. The integrated differentiated approach was applied in treatment. Before the removal of the cathe- ter had to resort to 3 cases. There were no deaths associated with complications of peritoneal dialysis. Conclusions. The effectiveness of peritoneal dialysis depends on the correct catheter implantation, the implementation of preventive measures to prevent infectious complications and disruption of the functioning of the catheter, timely diagnosis and pathogenetically substantiated treatment.

Key words: chronic kidney disease, peritoneal dialysis, catheter exit site infection, tunnel infection, peritonitis, pericateretric outflow of dialyzate, catheter migration.

\section{Адреса для листування:}

Кравець Олександр Валерійович

40007, Суми, вул. Римського-Корсакова, 2

Сумський державний університет,

медичний інститут,

кафедра загальної хірургії, радіаційної медицини та фтизіатрії

E-mail: kravets.oleksandr@ukr.net

Одержано 02.07.2018 